\title{
Physicians' perceived barriers to management of sexually transmitted infections in Vietnam
}

\author{
Khoi Do ${ }^{1}$, Victor Minichiello ${ }^{2}$, Rafat Hussain ${ }^{1 *}$ and Asaduzzaman Khan ${ }^{3}$
}

\begin{abstract}
Background: Sexually transmitted infections (STIs) are a public health problem in Vietnam with sub-optimal care in medical practice. Identifying practitioners' perceived barriers to STI care is important to improve care for patients with STIS.

Methods: A cross-sectional survey was conducted among 451 physicians. These physicians were dermatology and venereology (D\&V) doctors, obstetrical/gynaecological (Ob/Gyn) doctors, general practitioners, and assistant doctors working in health facilities at provincial, district and communal levels in three provinces in Vietnam.

Results: Almost all (99\%) respondents mentioned at least one barrier to STI care. The barriers were "lack of STI training" (57\%), "lack of professional resources" (41\%), "lack of time" (38\%), "lack of reimbursement" (21\%), "lack of privacy/ confidentiality" (17\%), "lack of counselling" (15\%), and "not the role of primary care provider" (7\%). Multivariable logistic regression analysis showed that "lack of professional resources" was associated with respondents being in medical practice for ten years or under (vs. 11-20 years), and working at district or communal health facilities (vs. provincial facilities); "lack of time" were associated with respondents being female, seeing more than 30 patients a week (vs. <15 patients/week); and "lack of privacy/confidentiality" was associated with physicians' seeing more than 30 patients a week (vs. $<15$ patients/week).
\end{abstract}

Conclusion: The study has identified several barriers to STI care in medical practice in Vietnam. Results of the study can be used to improve areas in STI care including policy and practice implications.

Keywords: Sexually transmitted infection, Physician, Barrier, Vietnam

\section{Background}

Sexually transmitted infections (STIs) are a major public health problem globally [1]. Without proper treatment, STIs can cause serious medical and psychological consequences and ultimately death [2]. In addition, STIs can facilitate transmission of HIV. It has been estimated that ulcerative STIs can increase HIV transmission risk by 10-50 times for male-to-female, and by $50-300$ times for female-to-male transmission, while non-ulcerative STIs can increase HIV transmission risk by $2-5$ times [3]. Two Cochrane reviews [4,5] found that although there is limited evidence for better STI control measures as a prevention strategy for HIV, there are, nonetheless, other compelling reasons for improving STI management $[4,5]$. Important among these are providing an increased

\footnotetext{
* Correspondence: rhussain@une.edu.au

${ }^{1}$ School of Rural Medicine, University of New England, Armidale, NSW 2350, Australia

Full list of author information is available at the end of the article
}

quality of service, and changing sexual behaviour such as promoting condom use and thereby having an impact on reducing the incidence of some of the STIs as well as HIV [6-8].

In Vietnam, the reported number of STIs increased more than six-fold between 1996 and 2010 [9]. It had been estimated that there were one million new STI cases in Vietnam annually $[10,11]$. Similarly, the reported number of HIV-positive cases increased almost 40 times between 1996 and 2013 [12,13]. Since 1986, Vietnam abandoned the central planning model of socialism and changed to a market oriented economy, known as Doi Moi. Under this renovation, the economy and the society have undergone significant changes such as decollectivization in agricultural production, development of private sector and foreign investment [14]. While the renovation has been successful in economic development, impacts on other aspects of society should be noted including unemployment, 
reduced availability of public health, increased inequality, widening income gap, increasing rural to urban migration $[15,16]$. These impacts have disproportionately affected women and some of them resorted to prostitution as a means to survive $[17,18]$. The emergence of sex work, together with inconsistent condom use, might have contributed to the increase in STI cases in Vietnam [19-21]. As for the health services, inconsistencies in physicians' practice such as insufficient risk assessment, improper diagnosis and treatment, inefficient behavioural change counselling could also be linked to the increase of STI cases [22-24].

Healthcare providers play a crucial role in reducing the burden of STI/HIV by providing effective STI prevention and case management [25]. However, while inadequacies in involvement of practitioners in offering optimal care for STI have been reported [26-28], it also needs to be acknowledged that the health care system and, how it is financed, influences the delivery of health services. Available data from Vietnam suggest there are issues in STI management such as the tendency to overdiagnose reproductive tract infections (RTIs) by clinicians and laboratory technicians [29], insufficient knowledge of STIs by physicians [22], and some patients felt that they were not being treated with respect such as being shouted at or scold by physicians and not satisfied with the services they receive at health facilities [30,31]. A better understanding of physicians' views on barriers in management of STIs is an important area of research to inform current policies and programmes in Vietnam. This study aimed to determine physicians' perception of barriers to STI services and factors related to such barriers.

\section{Methods}

A cross-sectional self-administered survey of 451 physicians working in three provinces (Quang Ninh, An Giang and Can Tho) of Vietnam was conducted in SeptemberNovember 2010. These provinces were identified as having a more serious STI/HIV problem in Vietnam [32]. Potential respondents were physicians in clinical practice at health facilities at provincial, district and communal levels. To be eligible, the respondents needed to be dermatology and venereology $(\mathrm{D} \& \mathrm{~V})$ doctors, obstetric/gynaecological $(\mathrm{Ob} /$ Gyn) doctors, general practitioners, or assistant doctors. As the number of $\mathrm{D} \& \mathrm{~V}$ doctors per province was small, all available D\&V doctors were included in the survey. Non $\mathrm{D} \& \mathrm{~V}$ physicians (Ob/Gyn doctors, general practitioners, or assistant doctors) were selected using a multi-stage sampling method where ten districts among the 29 districts in the three provinces were selected using simple random sampling and subsequently a systematic random sampling was conducted among the 10 selected districts to select the required number of physicians [33].
Vietnam is divided into provinces. The provinces are further divided into town and districts. Towns and districts are subsequently divided into communes [34]. The national authority in health is the Ministry of Health responsible for healthcare administration. The provincial health bureaus are under Ministry of Health in terms of technical management and under Provincial People's Committee in relation to governmental management. The primary level in healthcare network is district health centres and communal health stations [35]. In Vietnam, STI services are provided at general practice and D\&V specialised facilities, at public and private facilities. Patients can choose to go directly to $\mathrm{D} \& \mathrm{~V}$ facilities first without being referred from general practitioners.

Briefing meetings took place between the researcher and the potential respondents to introduce the survey to them and discuss any questions they might have. Respondents received an information pack containing a background information sheet, informed consent form, a copy of the survey questionnaire, and a return envelope. The respondents were given the option to complete the questionnaire immediately after the briefing meetings or at a later time. A financial incentive of AU\$5 was provided to all respondents for their time spent on completing the survey. Respondents who did not return the completed questionnaire on time received three reminders, in two-week interval, from either the researcher or from a staff member of the local health service. Full ethics approval for undertaking the study was granted by the Human Research Ethics Committee of the University of New England, Australia (HE10/148). Additional information about survey arrangement and health setting in Vietnam have been presented in a previously published paper [24].

\section{Statistical analysis}

Data for this paper were sourced from a sub-section of the questionnaire items dealing with management of STIs, and, in particular, perceived barriers to STI care. Perceived barriers to STI care were considered as outcome variables of interest for the present paper. The list of barriers include: "lack of time", "lack of reimbursement", "lack of privacy/confidentiality", "lack of counselling", "lack of professional resources", "lack of training in STI" were selected to be included in the questionnaire, based on literature review [36-39]. The independent variables considered in this analysis were physicians' age, sex, medical degree, training in STIs, training in communication with patients, duration of medical practice, average weekly client volume, STI diagnoses in the month prior to the survey, and place of main practice. These nine independent variables have been reported to be associated with STI knowledge and practice of physicians [36,40-46]. Independent variables found to be associated with outcome variables at $\mathrm{p} \leq 0.2$ (using Chi-square test) at univariable 
level were included in the base model of multivariable logistic regression [47]. In addition, "clinically plausible" relationships between the barriers were also examined.

Assumptions for logistic regression were checked to ensure that the fitted model was appropriate for the collected data. Assumptions for logistic regression included absence of multicollinearity and of outliers in the solution, and adequate sample size [48,49]. Variance Inflation Factor (VIF) value over 5 was used to determine multicollinearity [50]. Outliers were checked by examination of residuals. Cases with a standardised residual value over \pm 2.5 were removed from analysis [49]. The regression models were examined for goodness of fit using the Hosmer-Lemeshow Goodness of fit test; a good fit was indicated by a p-value greater than 0.05 . The Wald test was used to evaluate the importance of each of the independent variables. An independent variable was considered significantly associated with the outcome variable of interest if the associated p-value was less than 0.05 [49]. The multivariable logistic regression provided estimates of adjusted odds ratios and their $95 \%$ confidence intervals $(\mathrm{CI})$ for respondents' characteristics associated with perceived barriers to STI care. All data analysis was performed using SPSS, version 20 [51].

\section{Results}

\section{Respondent characteristics}

Of the physicians who participated in the study $(n=451)$, two-thirds (68.7\%) were females and one-third were males (31.3\%). While $10 \%$ of the participants were D\&V doctors, the remaining (90\%) were general physicians, Ob/Gyn doctors and assistant doctors. A quarter (26.4\%) had been in medical practice for ten years or less, over one-third had been in practice for 11-20 years (34.4\%), and the rest (39.2\%) had been in practice for over 20 years. Almost half (46.6\%) of the respondents had an average weekly patient volume of 15 or fewer; a quarter $(24.8 \%)$ of the sample saw $16-30$ patients and over a quarter (28.6\%) had more than 30 patients a week. Regarding the place of main practice, about half $(48.6 \%)$ of the respondents worked at communal health facilities, $20.2 \%$ of respondents worked at district health facilities and the rest (33\%) worked at provincial health facilities (see Table 1).

\section{Perceived barriers to STI care}

Almost all (98.9\%, data not shown) respondents mentioned at least one barrier to STI care. Over one-third (39.5\%) of the respondents mentioned one barrier, just less than one-third (29.9\%) two barriers, one-fifth $(20.6 \%)$ mentioned three barriers, and the rest of (8.9\%) listed four barriers or more. Among the barriers identified, the most common was "lack of STI training" (56.8\%). The second most common barrier was "lack of professional resources" (40.6\%), followed by "lack of time" (37.9\%). Other barriers included "lack of reimbursement" (21.1\%), "lack of privacy/
Table 1 Characteristics of survey respondents

\begin{tabular}{|c|c|}
\hline Respondents' characteristics & Total N (\%) \\
\hline \multicolumn{2}{|l|}{ Sex } \\
\hline Females & $310(68.7)$ \\
\hline Males & $141(31.3)$ \\
\hline \multicolumn{2}{|l|}{ Age group (in years) } \\
\hline$<40$ & $134(29.7)$ \\
\hline $40-50$ & $256(56.8)$ \\
\hline $51-60$ & $61(13.5)$ \\
\hline \multicolumn{2}{|l|}{ Medical degree } \\
\hline D\&V doctor & $47(10.4)$ \\
\hline Ob/Gyn doctor & $33(7.3)$ \\
\hline General practitioner & $110(24.4)$ \\
\hline Assistant doctor & $261(57.9)$ \\
\hline \multicolumn{2}{|l|}{ In-service training in STIS } \\
\hline No & $157(34.8)$ \\
\hline Yes & $294(65.2)$ \\
\hline \multicolumn{2}{|c|}{ In-service patient communication training } \\
\hline No & $204(45.2)$ \\
\hline Yes & $247(54.8)$ \\
\hline \multicolumn{2}{|c|}{ Duration of medical practice (in years) } \\
\hline$\leq 10$ & $119(26.4)$ \\
\hline $11-20$ & $155(34.4)$ \\
\hline$>20$ & $177(39.2)$ \\
\hline \multicolumn{2}{|l|}{ Average weekly client volume } \\
\hline$\leq 15$ & $210(46.6)$ \\
\hline $16-30$ & $112(24.8)$ \\
\hline$>30$ & $129(28.6)$ \\
\hline \multicolumn{2}{|c|}{ STI diagnoses in the month prior to the survey } \\
\hline No & $137(30.4)$ \\
\hline Yes & 314 (69.6) \\
\hline \multicolumn{2}{|l|}{ Place of main practice } \\
\hline Provincial facilities & $149(33)$ \\
\hline District facilities & $91(20.2)$ \\
\hline Communal health station & $211(46.8)$ \\
\hline
\end{tabular}

confidentiality" (17.3\%), "lack of counselling" (14.6\%). As for training needs of the respondents, the most common types of training needed were STI diagnosis (80.9\%), counselling of STI patients (61.9\%), STI prevention (50.3\%), and working with patients who identify themselves as sex workers, drug users, and/or homosexual (31.7\%). Distribution of barriers by respondents' characteristics is presented in Table 2 .

Assistant doctors were twice more likely than D\&V doctors to mention lack of STI training. Compared to respondents who had been in medical practice ten years or less, those who had been in medical practice for 11-20 years were less likely to mention "lack of professional 
Table 2 Perceived barriers for STI care by characteristics of respondents

\begin{tabular}{|c|c|c|c|c|c|c|}
\hline $\begin{array}{l}\text { Respondent } \\
\text { characteristics }\end{array}$ & $\begin{array}{c}\text { Lack of STI } \\
\text { training } N(\% *)\end{array}$ & $\begin{array}{l}\text { Lack of professional } \\
\text { resources } N\left(\%^{*}\right)\end{array}$ & $\begin{array}{l}\text { Lack of time } \\
N\left(\%^{*}\right)\end{array}$ & $\begin{array}{c}\text { Lack of } \\
\text { reimbursement } \mathrm{N}\left(\%^{*}\right)\end{array}$ & $\begin{array}{c}\text { Lack of privacy/ } \\
\text { confidentiality } \mathrm{N}\left(\%^{*}\right)\end{array}$ & $\begin{array}{c}\text { Lack of } \\
\text { counselling } \mathrm{N}\left(\%^{*}\right)\end{array}$ \\
\hline \multicolumn{7}{|l|}{ Sex } \\
\hline Female & $176(56.8 \%)$ & $131(42.3 \%)$ & $126(40.6 \%)$ & $69(22.3 \%)$ & $54(17.4 \%)$ & $44(14.2 \%)$ \\
\hline Male & $80(56.7 \%)$ & $52(36.9 \%)$ & 45 (31.9\%) & $26(18.4 \%)$ & $24(17.0 \%)$ & $22(15.6 \%)$ \\
\hline \multicolumn{7}{|l|}{$\begin{array}{l}\text { Age group } \\
\text { (in years) }\end{array}$} \\
\hline$<40$ & 87 (64.9\%) & $65(48.5 \%)$ & $50(37.3 \%)$ & $28(20.9 \%)$ & $26(19.4 \%)$ & $23(17.2 \%)$ \\
\hline $40-50$ & $138(53.9 \%)$ & $90(35.2 \%)$ & $93(36.3 \%)$ & $54(21.1 \%)$ & $42(16.4 \%)$ & $33(12.9 \%)$ \\
\hline $51-60$ & 31 (50.8\%) & $28(45.9 \%)$ & 28 (45.9\%) & $13(21.3 \%)$ & $10(16.4 \%)$ & $10(16.4 \%)$ \\
\hline \multicolumn{7}{|l|}{ Medical degree } \\
\hline D\&V doctor & $18(38.30 \%)$ & $13(27.70 \%)$ & $26(55.3 \%)$ & $11(23.4 \%)$ & $9(19.1 \%)$ & $3(6.40 \%)$ \\
\hline General practitioner & $67(60.9 \%)$ & $45(40.9 \%)$ & $30(27.3 \%)$ & $23(20.9 \%)$ & 20 (18.2\%) & $15(13.6 \%)$ \\
\hline Ob/Gyn doctor & $15(45.50 \%)$ & $12(36.4 \%)$ & $18(54.5 \%)$ & $11(33.3 \%)$ & $6(18.2 \%)$ & $5(15.2 \%)$ \\
\hline Assistant doctor & $156(59.8 \%)$ & $113(43.3 \%)$ & 97 (37.2\%) & $50(19.2 \%)$ & $43(16.5 \%)$ & $43(16.5 \%)$ \\
\hline \multicolumn{7}{|l|}{$\begin{array}{l}\text { In-service training } \\
\text { on STIs }\end{array}$} \\
\hline No & $109(69.4 \%)$ & 79 (50.3\%) & $44(28.0 \%)$ & $20(12.7 \%)$ & $28(17.8 \%)$ & $28(17.8 \%)$ \\
\hline Yes & $147(50.0 \%)$ & $104(35.4 \%)$ & $127(43.2 \%)$ & $75(25.5 \%)$ & $50(17.0 \%)$ & 38 (12.9\%) \\
\hline \multicolumn{7}{|l|}{$\begin{array}{l}\text { In-service training } \\
\text { on communication }\end{array}$} \\
\hline No & $126(61.8 \%)$ & $100(49.0 \%)$ & 61 (29.9\%) & $43(21.1 \%)$ & $44(21.6 \%)$ & $34(16.7 \%)$ \\
\hline Yes & $130(52.6 \%)$ & $83(33.6 \%)$ & 110 (44.5\%) & $52(21.1 \%)$ & $34(13.8 \%)$ & $32(13.0 \%)$ \\
\hline \multicolumn{7}{|l|}{$\begin{array}{l}\text { Duration of medical } \\
\text { practice (in years) }\end{array}$} \\
\hline$\leq 10$ & 76 (63.9\%) & $62(52.1 \%)$ & $44(37.0 \%)$ & $28(23.5 \%)$ & $23(19.3 \%)$ & $18(15.1 \%)$ \\
\hline $11-20$ & $93(60.0 \%)$ & 49 (31.6\%) & 47 (30.3\%) & $28(18.1 \%)$ & 31 (20.0\%) & $22(14.2 \%)$ \\
\hline$>20$ & 87 (49.2\%) & 72 (40.7\%) & 80 (45.2\%) & 39 (22.0\%) & $24(13.6 \%)$ & $26(14.7 \%)$ \\
\hline \multicolumn{7}{|l|}{$\begin{array}{l}\text { Average number } \\
\text { of patient seen } \\
\text { per week }\end{array}$} \\
\hline$\leq 15$ & $121(57.6 \%)$ & 88 (41.9\%) & 65 (31.0\%) & 38 (18.1\%) & 30 (14.3\%) & 25 (11.9\%) \\
\hline $16-30$ & $61(54.5 \%)$ & 47 (42.0\%) & 44 (39.3\%) & 25 (22.3\%) & 18 (16.1\%) & $11(9.8 \%)$ \\
\hline$>30$ & 74 (57.4\%) & 48 (37.2\%) & 62 (48.1\%) & 32 (24.8\%) & 30 (23.3\%) & $30(23.3 \%)$ \\
\hline \multicolumn{7}{|l|}{$\begin{array}{l}\text { STI diagnoses prior } \\
\text { to survey }\end{array}$} \\
\hline Yes & $174(55.4 \%)$ & $120(38.2 \%)$ & 117 (37.3\%) & 57 (18.2\%) & 51 (16.2\%) & 38 (12.1\%) \\
\hline No & 82 (59.9\%) & $63(46.0 \%)$ & $54(39.4 \%)$ & 38 (27.7\%) & 27 (19.7\%) & $28(20.4 \%)$ \\
\hline \multicolumn{7}{|l|}{$\begin{array}{l}\text { Place of main } \\
\text { practice }\end{array}$} \\
\hline Province & 77 (51.7\%) & $44(29.5 \%)$ & 79 (53.0\%) & 29 (19.5\%) & 29 (19.5\%) & $23(15.4 \%)$ \\
\hline District & $57(62.6 \%)$ & $43(47.3 \%)$ & 32 (35.2\%) & 19 (20.9\%) & 15 (16.5\%) & $13(14.3 \%)$ \\
\hline Commune & $122(57.8 \%)$ & 96 (45.5\%) & 60 (28.4\%) & 47 (22.3\%) & 34 (16.1\%) & 30 (14.2\%) \\
\hline
\end{tabular}

*Percentage of respondents who reported perceived barriers for STI care (row \%, Response = "No" was omitted).

resources". Respondents working at district and communal health facilities were more likely than those working at provincial level facilities to mention "lack of professional resources". Male physicians were less likely to mention "lack of time" than females. General practitioners were less likely to mention lack of time than D\&V doctors. Respondents seeing more than 30 patients a week were more likely to mention "lack of time" than those seeing 15 or fewer patients a week. Respondents who see more than 30 patients a week were also more likely to mention "lack of 
privacy/confidentiality" than those who see 15 or fewer patients a week (Table 3). At the bivariate level, lack of counselling was significantly associated with lack of privacy/ confidentiality $(\mathrm{p}<0.05)$. Respondents who mentioned lack of counselling were more likely to mention lack of privacy/ confidentiality.

\section{Discussion}

The respondents in the study reported a number of barriers to providing STI care in Vietnam. The barriers include a range of issues encountered in clinical interactions with patients such as lack of time, lack of availability of educational resources and training, lack of reimbursement, difficulties in maintaining privacy/confidentiality, and lack of counselling. Training has been identified as one of the major means of improving the quality of STI care $[52,53]$. Physicians' training has been reported to be associated with improved physicians' comfort with STI patients $[43,54]$; lower prejudicial attitude toward people living with HIV/AIDS [55]; improved skill for risk assessment, clinical examination, diagnosis and treatment [52]; more willingness to offer STI testing to patients [36]; improved patient adherence [56] and improved patient's outcomes [53].

Table 3 Logistic regression estimates of factors associated with perceived barriers for STI care

\begin{tabular}{|c|c|c|c|c|c|c|}
\hline & $\begin{array}{l}\text { Lack of STI } \\
\text { training }\end{array}$ & $\begin{array}{l}\text { Lack of } \\
\text { professional } \\
\text { resources }\end{array}$ & $\begin{array}{l}\text { Lack of time } \\
\text { Adj OR }\end{array}$ & $\begin{array}{l}\text { Lack of } \\
\text { reimbursement }\end{array}$ & $\begin{array}{l}\text { Lack of privacy/ } \\
\text { confidentiality }\end{array}$ & $\begin{array}{l}\text { Lack of } \\
\text { counselling }\end{array}$ \\
\hline & $\begin{array}{l}\text { Adj OR } \\
(95 \% \mathrm{Cl})\end{array}$ & $\begin{array}{c}\text { Adj OR } \\
(95 \% \mathrm{Cl})\end{array}$ & $(95 \% \mathrm{Cl})$ & $\begin{array}{c}\text { Adj OR } \\
(95 \% \mathrm{Cl})\end{array}$ & $\begin{array}{l}\text { Adj OR } \\
(95 \% \mathrm{Cl})\end{array}$ & $\begin{array}{c}\text { Adj OR } \\
(95 \% \mathrm{Cl})\end{array}$ \\
\hline Sex: Male (vs. Female) & - & - & $0.61(0.39-0.99)^{*}$ & - & - & - \\
\hline \multicolumn{7}{|l|}{ Age group (in years) } \\
\hline $40-50$ (vs. <40) & NS & NS & - & - & - & - \\
\hline $51-60$ (vs. <40) & NS & NS & - & - & - & - \\
\hline \multicolumn{7}{|l|}{ Medical degree } \\
\hline $\begin{array}{l}\text { General practitioner } \\
\text { (vs. D\&V doctor) }\end{array}$ & NS & NS & $0.43(0.19-0.99)^{*}$ & - & & - \\
\hline $\begin{array}{l}\text { Assistant doctor } \\
\text { (vs. D\&V doctor) }\end{array}$ & $2.06(1.04-4.05)^{*}$ & NS & NS & - & - & - \\
\hline $\begin{array}{l}\text { Ob/Gyn doctors } \\
\text { (vs. D\&V doctor) }\end{array}$ & NS & NS & NS & - & - & - \\
\hline $\begin{array}{l}\text { In-service training on STI: } \\
\text { Yes (vs. No) }\end{array}$ & $0.52(0.33-0.82)^{*}$ & NS & NS & NS & - & - \\
\hline $\begin{array}{l}\text { In-service training on } \\
\text { communication: Yes (vs. No) }\end{array}$ & NS & $0.64(0.40-0.96)^{*}$ & NS & - & NS & - \\
\hline \multicolumn{7}{|l|}{$\begin{array}{l}\text { Duration of medical practice } \\
\text { (in years) }\end{array}$} \\
\hline $11-20$ (vs. <10) & NS & $0.44(0.23-0.86)^{*}$ & NS & - & - & - \\
\hline$>20$ (vs. <10) & NS & NS & NS & - & - & - \\
\hline \multicolumn{7}{|l|}{ Average weekly client volume } \\
\hline $16-30$ (vs. <15) & - & - & NS & - & NS & - \\
\hline$>30$ (vs. <15) & - & - & $1.77(1.06-2.95)^{*}$ & - & $2.26(1.01-5.06)^{*}$ & - \\
\hline $\begin{array}{l}\text { STI diagnoses in the month } \\
\text { prior to the survey: }\end{array}$ & - & NS & - & NS & - & - \\
\hline \multicolumn{7}{|l|}{ Yes (vs. No) } \\
\hline \multicolumn{7}{|l|}{ Place of main practice } \\
\hline $\begin{array}{l}\text { District hosp./health centre } \\
\text { (vs. provincial facilities) }\end{array}$ & - & $2.23(1.24-4.01)^{*}$ & $0.46(0.25-0.84)^{*}$ & - & - & - \\
\hline $\begin{array}{l}\text { Communal health stations } \\
\text { (vs. provincial facilities) }\end{array}$ & - & $2(1.17-3.43)^{*}$ & $0.43(0.25-0.74)^{*}$ & - & - & - \\
\hline
\end{tabular}

${ }^{*} \mathrm{p} \leq 0.05$ (Wald statistic).

NS: not significant at multivariable logistic regression.

-Independent variables not significantly associated with dependant variable at $\mathrm{p} \leq 0.2$ at univarible logistic regression and not included in multivariable logistic regression. 
In the present study, over half of the respondents identified lack of STI training as a barrier to STI care. Moreover, the finding that half of the respondents who already had in-service STI training also identified "lack of STI training" as a barrier further underscores the need to review the existing STI training materials and refresher courses. The Law on Medical Examination and Treatment, which came into effect on January 1st, 2011, is expected to create important changes in continuing medical education (CME) in Vietnam. Under the Law, medical practitioners (doctors and assistant doctors) need to be licensed to practise medicine and they need to participate in CME at least once every two years in order to maintain their licence [57]. The CME framework in Vietnam is currently being developed, and therefore it may be timely to advocate for inclusion of an effective STI care module in the CME training programs.

Beyond training issues, another major barrier reported by physicians in the present study was lack of professional resources. Lack of professional resources has been identified as a barrier for physicians to provide healthcare services according to clinical guidelines [38,58,59]. Another Vietnamese study of health staff at communal level reported low satisfaction with training materials and technical guidelines $(50.4 \%)$, access to training and coaching (53.9\%), and professional training and coaching (57.6\%) [60]. In Vietnam, the National Guidelines for diagnosis and treatment of HIV/AIDS was released in 2009, and the National Guidelines for diagnosis and treatment of STIs was released in November 2013 [61,62]. These guidelines can be used as the principal reference sources for health staff for information regarding STIs and HIV/AIDS management in Vietnam. In addition to the availability of the guidelines for physicians, training on the new guidelines together with adequate supervision and feedback are needed to ensure physicians' compliance, which in turn can improve STI services. Perhaps, more intensive specialised training on sexual history taking, doctors assisting patients to feel more comfortable to seek sexual health care and new advances in treatment options should be considered.

Lack of time has been reported as a barrier for physicians' to adhere to clinical guidelines [38,58,59], to conduct sexual history taking and/or discuss with patients about sexual health issues [63-65], to offer HIV test to patients $[37,66]$. In the present study, lack of time was a common barrier among the physicians and this was more common among female physicians. This is also consistent with the literature that male physicians tend to spend less time taking a patient's sexual history or offering STI test to patients $[36,39,41]$. It could also be that female patients tend to prefer female physicians more than male physicians when seeking STI services $[67,68]$. In order to help physicians to deal with this issue, time saving tools for physicians need to be made available. The use of job aid such as flipcharts, flowchart may be effective and feasible in developing countries [69-71] and the physicians should be well equipped with these during their interactions with patients. Since sexual history taking can be time-consuming and often not well implemented $[24,41,72]$, improvement in this aspect is important to improve quality of STI service and to save physicians' time. To help physicians save time taking a patient's sexual history, the use of patient-administered sexual history taking instrument to help screen patients for STI risk has been successfully utilised elsewhere [73,74]. This patient-administered sexual history taking can be computer or paper-based [75-78]. The use of a computerised tool to elicit patients' sexual histories has the advantages of saving physicians' time, of being acceptable to both patients and physicians, of improving care for patients' specific needs by patient screening and routing, and of improving information collection, especially sensitive information $[74,79,80]$. While high literacy rates $[96.1 \%$ among males and 92\% among females] and a rapid increase in computer/Internet usage in Vietnam [0.3\% in 2000 to $34 \%$ in 2012] [81] may suggest that ACASI could be feasible for sexual history taking in Vietnam, further research in this area is necessary to evaluate the practicality of using this approach in a country like Vietnam, and whether patients and health professionals would access information on sexual health via e-technology.

Lack of privacy/confidentiality in health facilities in Vietnam, together with the judgmental attitudes of healthcare workers has resulted in delayed treatment for many STI cases [82]. Although patients privacy and confidentiality are stipulated in Vietnamese law [83,84], elaboration of these are limited in the medical curriculum and current national guidelines. In this regard, placing emphasis on developing a strong culture of patient rights and changing behaviours through simple interventions such as ensuring a closed door and limiting staff movement during consultations can help improving patients' privacy/confidentiality. The association between lack of privacy/confidentiality and lack of counselling may further compromise patient's access to comprehensive STI services and this should further investigated.

Another barrier to STI care is lack of counselling. Counselling is important to identify individuals at risk and promote behavioural changes [85-88]. In Vietnam, counselling is mostly provided by physicians to patients as part of the regular physician-patient interaction or in specialised counselling situations, such as during HIV voluntary testing and counselling, prevention of motherto-child transmission of HIV. However, the quality and delivery of counselling varies among services [89-91]. Physicians' perceived time pressure may also require consideration. For instance, other healthcare professionals, like nurses and midwives, could assume responsibility for 
patient counselling to alleviate physician time constraints [92-94]. However, these allied health staff should be adequately trained on counselling before they are assigned for this new responsibility. Additionally, counselling can be included in both undergraduate and post-graduation medical education programs along with CME programs in order to ensure that the physicians have the skills necessary to providing most appropriate counselling. In this study, the low proportion of respondents mentioning lack of counselling should be investigated more deeply in further studies since as this may suggest the limited awareness of physicians of what constitutes appropriate and relevant sexual health counselling.

Finally, amongst the key barriers to STI care reported by physicians in the present study, two out of every ten respondents mentioned lack of reimbursement. Lack of reimbursement has been identified as a barrier for physicians to screen patients for HIV $[37,66]$ and to adhere to medical guidelines [38] and that financial incentive has been reported to be effective in changing physicians' practice [95], also that financial incentive together with reminder and feedback may be more effective than incentive only [96]. A survey in Vietnam reported that salary levels and lack of incentives were the highest cause of job dissatisfaction in healthcare [60]. While it can be hypothesized that improvement in physicians' reimbursement can lead to improvements in STI services, it is necessary to investigate the cost-effectiveness of this approach versus other approaches. For example, further research might examine whether providing higher remuneration to doctors from poor districts would result in higher quality STI care delivery and better STI management.

The limitations of this study need to be acknowledged. Self-reported responses can be subject to social desirability bias with the respondents choosing the responses which they regard as desirable rather than reporting their actual practices [97]. However, the use of surveys for eliciting information from healthcare providers is a common research methodology [54,98-100]. In our study, the respondents were briefed by one of the researchers on the nature of the survey including its purpose and methods, the assurances of the confidentiality of the respondents' information, and their right to participate or withdraw from the survey. During the briefing, the respondent physicians were made aware of the confidentiality of study results that no personal identifiable would be reported. It was expected that this could reduce bias. Another concern with the study relates to the representativeness of the sample. Our sample of physicians contained a higher proportion of assistant doctors and females than the national average. In Vietnam, there were 7.2 doctors and 6.22 assistant doctors per 100,000 population [101]. Also, our sample did not include physicians in private practice and had a higher representation of $\mathrm{D} \& \mathrm{~V}$ doctors in the sample.
However, it is believed that most physicians in Vietnam were in dual practices, who work both in the government and private sector $[102,103]$. This suggests non-representativeness of the sample in relation to the health workforce profile in Vietnam. Therefore, caution is needed in interpreting and generalising the findings of this study to all regions of Vietnam. This study was limited in its geographic scope by funding and other resource constraints. Another limitation of the study is that the list of barriers was pre-defined based on available literature. Although an "Other, please specify" response was made available, physicians' responses might be subject to priming effect where respondents' responses may be influenced by the response categories already listed [104]. Although the respondents were instructed to tick the response/s that applied to them, the response category "No barrier" was not available which could lead to bias in responses. Future research studies may benefit from a more exhaustive list of barriers or an open-ended question where the respondents are required to list the barriers themselves. Furthermore, a behavioural model incorporating perceived barriers should be used in the development of questionnaire as well as interpretation of findings [105,106]. Future studies should be carried out on a much larger nationally representative sample of physicians to provide better representation of issues in the management of STIs in Vietnam.

\section{Conclusions}

This study has identified several barriers to STI care in medical practice in Vietnam. The findings are discussed in the context of evidence from other research studies as well as programmatic issues in health service provision in Vietnam. Results of the study can be used to improve areas in STI care including policy and practice implications.

\section{Competing interests}

The authors declare that they have no competing interests.

\section{Authors' contributions}

$\mathrm{KD}$ designed the study, analysed the data, interpreted the data analysis and contributed to manuscript writing. VM, RH and AK contributed to designing the study, interpreting the results, and writing the manuscript. All authors read and approved the final manuscript.

\section{Acknowledgements}

The authors acknowledge the financial contribution made by the Collaborative Research Network on Mental Health and Well-Being in Rural Communities, supported by the Department of Industry, Innovation, Science, Research and Tertiary Education, Commonwealth Government of Australia.

\section{Author details}

${ }^{1}$ School of Rural Medicine, University of New England, Armidale, NSW 2350, Australia. ${ }^{2}$ School of Medicine and Public Health, University of Newcastle \& Emeritus Professor, University of New England, Armidale, NSW 2350, Australia. ${ }^{3}$ School of Health and Rehabilitation Sciences, The University of Queensland, Armidale, NSW 2350, Australia.

Received: 25 March 2014 Accepted: 21 October 2014

Published: 4 November 2014 


\section{References}

1. Rowley J, Toskin I, Ndowa F: Global incidence and prevalence of selected curable sexually transmitted infections, 2008. Geneva: World Health Organization; 2012.

2. Da Ros C, da Silva SC: Global epidemiology of sexually transmitted diseases. Asian J Androl 2008, 10:110-114.

3. Crawford DH: Virus Hunt: The search for the origin of HIV/AIDs. Oxford: Oxford University Press; 2013.

4. Sangani P, Rutherford G, Wilkinson D: Population-based interventions for reducing sexually transmitted infections, including HIV infection. Cochrane Database Syst Rev 2004, 2:1-23.

5. Ng BE, Butler LM, Horvath T, Rutherford GW: Population-based biomedical sexually transmitted infection control interventions for reducing HIV infection. Cochrane Database Syst Rev 2011, 16:1-44.

6. Korenromp E, White R, Orroth K, Bakker R, Kamali A, Serwadda D, Gray R, Grosskurth H, Habbema J, Hayes R: Determinants of the impact of sexually transmitted infection treatment on prevention of HIV infection: a synthesis of evidence from the Mwanza, Rakai, and Masaka intervention trials. J Infect Dis 2005, 191:S168.

7. Padian NS, Buve A, Balkus J, Serwadda D, Cates W: Biomedical interventions to prevent HIV infection: evidence, challenges, and way forward. Lancet 2008, 372:585-599.

8. White R, Celum C, Wasserheit J, Aral S, Hayes R: Control of sexually transmitted infections for HIV prevention. Lancet 2008, 372:1297.

9. Situation analysis of sexually transmissible infections in Vietnam [Internet]. http://tiengchuong.vn/Nghien-cuu-Chuyen-de/Benh-lay-truyenqua-duong-tinh-duc-Nhung-dieu-can-biet/6630.vgp.

10. Ministry of Health: Action plan for STI prevention and control till 2010. Hanoi: 2007.

11. World Health Organization: Consensus report on STI, HIV and AIDS epidemiology Vietnam. Hanoi: 2000.

12. San PB, Dzung PH, Hong KT, Oanh KTH, Tuan T: Evaluation of the National AIDS program January 1996 - June 2001 in Vietnam. Hanoi: National AIDS Standing Bureau; 2002

13. HIV/AIDS epidemic in the first six month of 2013. http://www.vaac.gov. vn/Desktop.aspx/Noi-dung/Tinh-hinh-dich-so-lieu-HIVAIDS/ Tinh_hinh_dich_HIVAIDS_6_thang_dau_nam_2013/.

14. Witter S: 'Doi moi' and health: the effect of economic reforms on the health system in Vietnam. Int J Health Plann Manage 1996, 11:159-172.

15. Beresford M: Doi Moi in review: the challenges of building market socialism in Vietnam. J Contemp Asia 2008, 38:221-243.

16. Anh LT, Hoang Vu L, Bonfoh B, Schelling E: An analysis of interprovincial migration in Vietnam from 1989 to 2009. Glob Health Action 2012, 5:1-12.

17. Tran $\mathrm{T}$, Detels $\mathrm{R}$, Lan $\mathrm{H}$ : Condom use and its correlates among female sex workers in Hanoi, Vietnam. AIDS Behav 2006, 10:159-167.

18. Rushing R: Migration and sexual exploitation in Vietnam. Asian Pac Migrat J 2006, 15:471.

19. Van Nguyen H, Dunne MP, Debattista J: Risks for HIV infection among male street laborers in urban Vietnam. J Community Health 2013, 38:626-633.

20. Tran $T$, Le $\mathrm{CL}$, Nguyen TL: Factors associated with inconsistent condom use among female sex workers in Nha Trang, Vietnam. Asia Pac J Public Health 2008, 20:370-378.

21. Phinney HM: "Rice is essential but tiresome; you should get some noodles": Doi Moi and the political economy of men's extramarital sexual relations and marital HIV risk in Hanoi, Vietnam. Am J Public Health 2008, 98:650.

22. Quach L, Mayer K, McGarvey ST, Lurie MN, Do P: Knowledge, attitudes, and practices among physicians on HIV/AIDS in Quang Ninh, Vietnam. AIDS Patient Care ST 2005, 19:335-346.

23. Lan PT: Sexually transmitted infections and other reproductive tract infections in rural Vietnam: current situation, management and implications for control. Karolinska Institute; 2009.

24. Do K, Minichiello V, Hussain R, Khan A: Sexual history taking in general practice: managing sexually transmitted infections for female sex workers by doctors and assistant doctors in Vietnam. Int J STD AIDS 2014, doi:0956462414529553.

25. World Health Organization: Sexually transmitted and other reproductive tract infections. A quide to essential practice. Geneva: 2005.

26. Khan A, Plummer D, Hussain R, Minichiello V: Preventing sexually transmissible infections in Australian general practice. Int J STD AIDS 2008, 19:459-463.
27. Gott M, Galena E, Hinchliff S, Elford H: "Opening a can of worms": GP and practice nurse barriers to talking about sexual health in primary care. Fam Pract 2004, 21:528.

28. Haley N, Maheux B, Rivard M, Gervais A: Sexual health risk assessment and counseling in primary care: how involved are general practitioners and obstetrician-gynecologists? Am J Public Health 1999, 89:899-902.

29. Nguyen MH, Gammeltoft T, Christoffersen SV, Tran TT, Rasch V: Reproductive tract infections in northern Vietnam: health providers' diagnostic dilemmas. Women Health 2009, 49:229-245.

30. Lan P, Faxelid E, Chuc N, Mogren I, Lundborg C: Perceptions and attitudes in relation to reproductive tract infections including sexually transmitted infections in rural Vietnam: A qualitative study. Health Policy 2008, 86:308-317.

31. Ngo A, Ratliff E, McCurdy S, Ross M, Markham C, Pham H: Health seeking behaviour for sexually transmitted infections and HIV testing among female sex workers in Vietnam. AIDS Care 2007, 19:878-887.

32. Ministry of Health: Results from the HIV/STI Integrated Biological and Behavioral Surveillance (IBBS) in Vietnam. 2009.

33. Walker J, Maddan S: Statistics in criminology and criminal justice: analysis and interpretation. Burlington, MA: Jones \& Bartlett Learning; 2008.

34. Statistical yearbook of Vietnam 2012. http://gso.gov.vn/default.aspx? tabid $=512 \&$ idmid $=5 \& \mid$ tem $\mid D=13760$.

35. Tran VT, Hoang TP, Inke M, Nguyen TKP: A health financing review of Vietnam with a focus on social health insurance. Geneva: World Health Organisation; 2011

36. Khan A, Hussain R, Plummer D, Minichiello V: Willingness to offer chlamydia testing in general practice in New South Wales. Aust N Z J Public Health 2006, 30:226-230.

37. Burke RC, Sepkowitz KA, Bernstein KT, Karpati AM, Myers JE, Tsoi BW, Begier EM: Why don't physicians test for HIV? A review of the US literature. AIDS 2007, 21:1617-1624.

38. Lugtenberg M, Zegers-van Schaick JM, Westert GP, Burgers JS: Why don't physicians adhere to guideline recommendations in practice? An analysis of barriers among Dutch general practitioners. Implement Sci 2009, 4:54.

39. Khan A, Plummer D, Hussain R, Minichiello V: Sexual risk assessment in general practice: evidence from a New South Wales survey. Sex Health 2007, 4:1-8.

40. Wiesenfeld HC, Dennard-Hall K, Cook RL, Ashton M, Zamborsky T, Krohn MA: Knowledge about sexually transmitted diseases in women among primary care physicians. Sex Transm Dis 2005, 32:649-653.

41. Wimberly YH, Hogben M, Moore-Ruffin J, Moore SE, Fry-Johnson Y: Sexual history taking among primary care physicians. J Natl Med Assoc 2006, 98:1924-1929.

42. Chan RK, Tan HH, Chio MT, Sen P, Ho KW, Wong ML: Sexually transmissible infection management practices among primary care physicians in Singapore. Sex Health 2008, 5:265-271.

43. Tsimtsiou Z, Hatzimouratidis K, Nakopoulou E, Kyrana E, Salpigidis G, Hatzichristou D: Predictors of physicians' involvement in addressing sexual health issues. JSM 2006, 3:583-588.

44. Montano DE, Phillips WR, Kasprzyk D, Greek A: STD/HIV prevention practices among primary care clinicians: risk assessment, prevention counseling, and testing. Sex Transm Dis 2008, 35:154-166.

45. Wenghofer EF, Williams AP, Klass DJ: Factors affecting physician performance: implications for performance improvement and governance. Health Policy 2009, 5:e141-e160.

46. Verhoeven V, Bovijn K, Helder A, Peremans L, Hermann I, Van Royen P, Denekens J, Avonts D: Discussing STIs: doctors are from Mars, patients from Venus. Fam Pract 2003, 20:11-15.

47. Hosmer DW Jr, Lemeshow S, Sturdivant RX: Applied logistic regression, 3rd ed. Hoboken, NJ: Wiley; 2013.

48. Pallant J: SPSS Survival Manual. 4th edition. Sydney, Australia: Allen and Unwin; 2011.

49. Tabachnick BG, Fidell L: Using multivariate statistics. 6th edition. Boston: Pearson; 2012

50. James G, Witten D, Hastie T, Tibshirani R: An introduction to statistical learning. New York: Springer; 2013.

51. IBM Corp: IBM SPSS Statistics for Windows, Version 20.0. Armonk, NY: IBM Corp; 2011.

52. Dreisbach S, Devine S, Fitch J, Anderson T, Lee T, Rietmeijer C, Corbett KK: Can experiential-didactic training improve clinical STD practices? Sex Transm Dis 2011, 38:516-521. 
53. Rackal JM, Tynan AM, Handford CD, Rzeznikiewiz D, Agha A, Glazier R: Provider training and experience for people living with HIV/AIDS. Cochrane Database Syst Rev 2011, 1-32.

54. Khan A, Plummer D, Hussain R, Minichiello V: Does physician bias affect the quality of care they deliver? Evidence in the care of sexually transmitted infections. Sex Transm Infect 2008, 84:150.

55. Li LWZ, Wu S, Zhaoc Y, Jia M, Yan Z: HIV-related stigma in health care settings: a survey of service providers in China. AIDS Patient Care ST 2007, 21:753-762.

56. Zolnierek KBH, DiMatteo MR: Physician communication and patient adherence to treatment: a meta-analysis. Med Care 2009, 47:826.

57. The National Assembly: Law on medical examination and treatment. Hanoi: 2009.

58. Taba P, Rosenthal M, Habicht J, Tarien H, Mathiesen M, Hill S, Bero L: Barriers and facilitators to the implementation of clinical practice guidelines: a cross-sectional survey among physicians in Estonia. BMC Health Serv Res 2012, 12:455.

59. McGowan CE, Monis A, Bacon BR, Mallolas J, Goncales FL, Goulis I, Poordad F, Afdhal N, Zeuzem S, Piratvisuth T, Marcellin P, Fried MW: A global view of hepatitis C: physician knowledge, opinions, and perceived barriers to care. Hepatology 2013, 57:1325-1332.

60. Tran BX, Van Hoang M, Nguyen HD: Factors associated with job satisfaction among commune health workers: implications for human resource policies. Glob Health Action 2013, 6:1-6.

61. Ministry of Health: Guidelines for diagnosis and treatment of STDs. Hanoi: 2013

62. Ministry of Health: Guidelines for diagnosis and treatment of HIV/AIDS. Hanoi: 2009

63. Barber B, Hellard M, Jenkinson R, Spelman T, Stoove M: Sexual history taking and sexually transmissible infection screening practices among men who have sex with men: a survey of Victorian general practitioners. Sex Health 2011, 8:349-354.

64. Dyer K, das Nair R: Why don't healthcare professionals talk about sex? A systematic review of recent qualitative studies conducted in the United Kingdom. J Sex Med 2013, 10:2658-2670.

65. Carter JW Jr, Hart-Cooper GD, Butler MO, Workowski KA, Hoover KW: Provider barriers prevent recommended sexually transmitted disease screening of HIV-infected men who have sex with men. Sex Transm Dis 2014, 41:137-142.

66. White BL, Walsh J, Rayasam S, Pathman DE, Adimora AA, Golin CE: What makes me screen for HIV? Perceived barriers and facilitators to conducting recommended routine HIV testing among primary care physicians in the Southeastern United States. J Int Assoc Provid AIDS Care 2014, doi:2325957414524025.

67. Grewal S, Bottorff JL, Balneaves LG: A Pap test screening clinic in a South Asian community of Vancouver, British Columbia: Challenges to maintaining utilization. Public Health Nurs 2004, 21:412-418.

68. Julliard K, Vivar J, Delgado C, Cruz E, Kabak J, Sabers H: What Latina patients don't tell their doctors: a qualitative study. Ann Fam Med 2008, 6:543-549.

69. Raney L, Joyce S, Townsend JW: Improving the quality of reproductive health care: How much does it cost? Washington, DC: Population Reference Bureau; 2003.

70. Kotwal N, Khan N, Kaul S: A review of the effectiveness of the interventions on adolescent reproductive health in developing countries. IJSRP 2014, 4:1-4.

71. Steen TW, Seipone K, de la Hoz GF, Anderson MG, Kejelepula M, Keapoletswe K, Moffat HJ: Two and a half years of routine HIV testing in Botswana. JAIDS 2007, 44:484-488.

72. Sobecki JN, Curlin FA, Rasinski KA, Lindau ST: What we don't talk about when we don't talk about sex: results of a national survey of US obstetrician/gynecologists. J Sex Med 2012, 9:1285-1294.

73. Fairley CK, Sze JK, Vodstrcil LA, Chen MY: Computer-assisted self interviewing in sexual health clinics. Sex Transm Dis 2010, 37:665-668.

74. Vodstrcil LA, Hocking JS, Cummings R, Chen MY, Bradshaw CS, Read TR, Sze JK, Fairley CK: Computer-assisted self interviewing in a sexual health clinic as part of routine clinical care; impact on service and patient and clinician views. PLoS One 2011, 6:e18456.

75. Heijman TLJ, van der Bij AK, de Vries HJC, van Leent EJM, Thiesbrummel HFJ, Fennema HSA: Effectiveness of a risk-based visitor-prioritizing system at a sexually transmitted infection outpatient clinic. Sex Transm Dis 2007 , 34:508-512.
76. Tideman RL, Chen MY, Pitts MK, Ginige S, Slaney M, Fairley CK: A randomised controlled trial comparing computer-assisted with face-to-face sexual history taking in a clinical setting. Sex Transm Infect 2007, 83:52-56.

77. Tobkin JA: Healthcare provider evaluation of a sexual history questionnaire at a public health clinic. North Dakota State University; 2011.

78. Elzevier HW, der Zalm PJ V-V, Pelger RC: How reliable is a self-administered questionnaire in detecting sexual abuse: a retrospective study in patients with pelvic-floor complaints and a review of literature. J Sex Med 2007, 4:956-963.

79. Pappas Y, Anandan C, Liu J, Car J, Sheikh A, Majeed A: Computer-assisted history-taking systems (CAHTS) in health care: benefits, risks and potential for further development. Inform Prim Care 2011, 19:155-160.

80. Doyle RJ, Wang N, Anthony D, Borkan J, Shield RR, Goldman RE: Computers in the examination room and the electronic health record: physicians' perceived impact on clinical encounters before and after full installation and implementation. Fam Pract 2012, 29:601-608.

81. Vietnam - The world factbook. https://www.cia.gov/library/publications/ the-world-factbook/geos/vm.html.

82. Nguyen TV, Van Khuu N, Le Thi TT, Nguyen AP, Cao V, Tham DC, Detels R: Sexually transmitted infections and risk factors for gonorrhea and chlamydia in female sex workers in Soc Trang, Vietnam. Sex Transm Dis 2008, 35:935-940.

83. The National Assembly: Law on infectious diseases prevention. Hanoi: 2007

84. The National Assembly: Law on protection of people's health. Hanoi: 1989.

85. Crepaz N, Lyles CM, Wolitski RJ, Passin WF, Rama SM, Herbst JH, Purcell DW, Malow RM, Stall R: Do prevention interventions reduce HIV risk behaviours among people living with HIV? A meta-analytic review of controlled trials. AIDS 2006, 20:143-157.

86. Crepaz N, Horn AK, Rama SM, Griffin T, Deluca JB, Mullins MM, Aral SO: The efficacy of behavioral interventions in reducing HIV risk sex behaviors and incident sexually transmitted disease in black and Hispanic sexually transmitted disease clinic patients in the United States: a meta-analytic review. Sex Transm Dis 2007, 34:319-332.

87. Allen S, Meinzen-Derr J, Kautzman M, Zulu I, Trask S, Fideli U, Musonda R, Kasolo F, Gao F, Haworth A: Sexual behavior of HIV discordant couples after HIV counseling and testing. AIDS 2003, 17:733.

88. Lin JS, Whitlock E, O'Connor E, Bauer V: Behavioral counseling to prevent sexually transmitted infections: a systematic review for the U.S. Preventive Services Task Force. Ann Intern Med 2008, 149:497-508. W496-499.

89. Hạnh NTT, Rasch V, Chi BK, Gammeltoft T: Posttest counseling and social support from health staff caring for HIV-infected pregnant women in Vietnam. J Assoc Nurses AIDS Care 2009, 20:193-202.

90. Hanh NTT, Gammeltoft T, Rasch V: Early uptake of HIV counseling and testing among pregnant women at different levels of health facilities-experiences from a community-based study in Northern Vietnam. BMC Health Serv Res 2011, 11:29.

91. Hong NT, Wolfe MI, Dat TT, McFarland DA, Lamb ML, Thang NT, Thai HN, Del Rio C: Utilisation of HIV voluntary counseling and testing in Vietnam: an evaluation of 5 years of routine program data for national response. AIDS Educ Prev 2011, 23:30-48.

92. Dreier A, Rogalski H, Oppermann RF, Terschüren C, Van Den Berg N, Hoffmann W: A curriculum for nurses in Germany undertaking medicallydelegated tasks in primary care. J Adv Nurs 2010, 66:635-644.

93. McPake B, Mensah K: Task-shifting in health care in resource-poor countries. Lancet 2008, 372:870-871.

94. Ivers LC, Jerome J-G, Cullen KA, Lambert W, Celletti F, Samb B: Task-shifting in HIV care: a case study of nurse-centered community-based care in rural Haiti. PLOS One 2011, 6:e19276.

95. Flodgren G, Eccles MP, Shepperd S, Scott A, Parmelli E, Beyer FR: An overview of reviews evaluating the effectiveness of financial incentives in changing healthcare professional behaviours and patient outcomes. Cochrane Database Syst Rev 2011, 1-94.

96. Bilardi JE, Fairley CK, Temple-Smith MJ, Pirotta MV, McNamee KM, Bourke S, Gurrin LC, Hellard M, Sanci LA, Wills MJ: Incentive payments to general practitioners aimed at increasing opportunistic testing of young women for chlamydia: a pilot cluster randomised controlled trial. BMC Public Health 2010, 10:70.

97. Ting JS: Social desirability bias in self-rated presenteeism among resident physicians. JAMA Intern Med 2013, 173:165-166.

98. Wright A, Soran C, Jenter CA, Volk LA, Bates DW, Simon SR: Physician attitudes toward health information exchange: results of a statewide survey. J Am Med Inform Assoc 2010, 17:66-70. 
99. Bosslet GT, Torke AM, Hickman SE, Terry CL, Helft PR: The patient-doctor relationship and online social networks: results of a national survey. J Gen Intern Med 2011, 26:1168-1174.

100. Donelan K, DesRoches CM, Dittus RS, Buerhaus P: Perspectives of physicians and nurse practitioners on primary care practice. N Engl J Med 2013, 368:1898-1906.

101. World Health Organisation: Viet Nam health service delivery profile. 2012.

102. Witter S, Thi Thu Ha B, Shengalia B, Vujicic M: Understanding the 'four directions of travel': qualitative research into the factors affecting recruitment and retention of doctors in rural Vietnam. Hum Resour Health 2011, 9:20.

103. Hipgrave DB, Hort K: Dual practice by doctors working in South and East Asia: a review of its origins, scope and impact, and the options for regulation. Health Policy Plan 2014, 29:703-716.

104. Brace I: Questionnaire Design how to Plan, Structure and Write Survey Material for Effective Market Research. London; Philadelphia: Kogan Page; 2008.

105. Michie S, Robert W, Rona C, Jamie B, Heather G: ABC of behaviour change theories. Great Britain: Silverback Publishing; 2014.

106. Cabana M, Rand C, Powe N, Wu A, Wilson M, Abboud P, Rubin H: Why don't physicians follow clinical practice guidelines?: a framework for improvement. JAMA 1999, 282:1458.

doi:10.1186/1471-2458-14-1133

Cite this article as: Do et al.: Physicians' perceived barriers to

management of sexually transmitted infections in Vietnam. BMC Public Health 2014 14:1133.

\section{Submit your next manuscript to BioMed Central and take full advantage of:}

- Convenient online submission

- Thorough peer review

- No space constraints or color figure charges

- Immediate publication on acceptance

- Inclusion in PubMed, CAS, Scopus and Google Scholar

- Research which is freely available for redistribution 